\title{
水道栓に生じた浸食の事例解析*
}

\author{
坂本晃大**, 山崎拓也 ${ }^{* *}$, 松村昌信** \\ ** 広島大学工学部
}

\section{Analysis of Corrosion Damage on Water Tap*}

\author{
Akihiro Sakamoto**, Takuya Yamasaki** and Masanobu Matsumura** \\ ** Faculty of Engineering, Hiroshima University
}

\begin{abstract}
Most of the water taps for domestic use are made of copper alloys. Their valve seats occasionally suffer damage due to corrosion and erosion as a result of water quality and seemingly cavitation respectively. The examination of damage mechanism and the development of testing methodology for selecting the durable materials to the attack were requested. In order to understand and solve these problems completely, erosion-corrosion tests were carried out on various copper alloys (five brasses and five bronzes) by using three test methods : (a) the ISO 6509 dezincification test for pure corrosion ; (b) the vibratory cavitation test with eccentric stationary specimen for cavitation erosion-corrosion; and (c) the Jet-in-Slit test for flow induced localized corrosion. The materials tested were ranked in different orders of merit according to the results obtained in the three test methods. Among these rankings, the one obtained in the Jet-in-Slit test has agreed upon with the ranking order that had been determined by experiences of field engineers who engaged themselves with the troubles under practical conditions. Hence it was concluded that the damage on valve seats has been caused by the flow induced localized corrosion, and the Jet-in-Slit was recommended as the reliable test method in selecting durable valve seat materials.
\end{abstract}

Key words : water tap, copper alloys, flow induced localized corrosion, cavitation erosion-corrosion

\section{1. 緒言}

一般の家庭で数多く使用されている水栓のほとんどは 銅合金製である。栓の外面はクロムめっきや，特に最近 では塗膜が施されているが, 内面は直接井戸水や水道水 に接している。このため水栓に用いられる素材の材質の 選定においては，原料費，加工費に並んで耐食性も重要 な要素となる。亜鉛の価格は錫のそれの四分の一程度で あるので黄銅（銅-亜鉛合金）は青銅（銅-錫合金）に 比べて原料費の点では有利であるが, 脱亚鉛腐食という 弱点がある。アルミニウム青銅は, アルミニウムが亜鉛 より安いので原料費の面で有利であるばかりでなく, 機 械的および化学的性質 (耐食性) に特に優れている。し かし, アルミニウムが酸化されやすいので生産管理が難 しい上，加工費が高いのでほとんど用いられていない。

* 第 41 回腐食防食討論会（松山, 1994）で発表

** 干739 東広島市鏡山 1-4-1（1-4-1, Kagamiyama, Higashi-Hiroshima, 739 Japan)
Table 1 は現在国内で水栓に用いられている, あるいは 使用が検討されている青銅および黄銅の一覧である。耐 脱亜鉛腐食黄銅（DZPB I, II）以外は JIS で規格化さ れている。

水栓で最も重要な部位は弁座である。そこに生じた浸 食の一例を Fig.1 に示す。この弁座は青銅製で口径は 9 $\mathrm{mm}$, 井戸水環境で 6 年間使用された。弁座の縁に小さ な欠陥があって, そこからの流出によって浸食が成長し たものと思われる。内圧や流速によってはキャビテー ションが生じたかもしれない。

この種の浸食に対処するためには，(1）浸食機構の 解明，（2）浸食に強い材料を選定するための試験法の 開発，が必要である。しかし機構解明のためにはまずこ の浸食を実験室で再現する必要があるが，それには長時 間（例えばFig. 1 の事例を再現するには 6 年）を要す る。そのため, 条件を厳しくして加速試験を行わざるを 得ないが, 現場と異なる条件下でその浸食機構が再現で 
Table 1 Chemical composition of copper alloys for water tap use.

\begin{tabular}{|c|c|c|c|c|c|c|c|c|c|c|c|c|c|}
\hline \multicolumn{2}{|r|}{ Material } & \multirow{4}{*}{$\begin{array}{l}\text { JIS } \\
\text { Symbol } \\
\text { BCIn } 1\end{array}$} & \multicolumn{11}{|c|}{ Chemical composition $[\%]$} \\
\hline & & & $\mathrm{Cu}$ & $\mathrm{Zn}$ & $\mathrm{Pb}$ & $\mathrm{Ni}$ & $\mathrm{Sn}$ & $\mathrm{Fe}$ & $P$ & Al & Sb & $\mathrm{Si}$ & As \\
\hline \multirow{7}{*}{ Bronze } & \multirow{4}{*}{ Bronze Ingots for Castings } & & $79 \sim$ & $8 \sim$ & $3 \sim$ & 0.8 & $2 \sim$ & 0.35 & 0.03 & 0.005 & 0.2 & 0.005 & - \\
\hline & & & 87 & 12 & 7 & $\downarrow$ & 4 & $\downarrow$ & $\downarrow$ & $\downarrow$ & $\downarrow$ & $\downarrow$ & \\
\hline & & $\mathrm{BC} \ln 6$ & $83 \sim$ & $4 \sim$ & $4 \sim$ & 0.8 & 4〜 & 0.3 & 0.03 & 0.005 & 0.2 & 0.005 & - \\
\hline & & & 87 & 6 & 6 & $\downarrow$ & 6 & $\downarrow$ & $\downarrow$ & $\downarrow$ & $\downarrow$ & $\downarrow$ & \\
\hline & \multirow{3}{*}{ Bronze Castings } & BC 1 & ${ }_{83}^{79 \sim}$ & ${ }_{12}^{8 \sim}$ & $3 \sim 7$ & $\begin{array}{c}1.0 \\
\downarrow\end{array}$ & $2 \sim$ & $\begin{array}{c}0.35 \\
\downarrow\end{array}$ & $\begin{array}{c}0.05 \\
\downarrow\end{array}$ & $\begin{array}{c}0.01 \\
\downarrow\end{array}$ & $\begin{array}{l}0.2 \\
\downarrow\end{array}$ & $\begin{array}{c}0.01 \\
\downarrow\end{array}$ & - \\
\hline & & $\mathrm{BC} 1 \mathrm{C}$ & $\begin{array}{r}79 \sim \\
83\end{array}$ & ${ }_{12}^{8 \sim}$ & $\begin{array}{l}3 \sim 7 \\
7\end{array}$ & $\begin{array}{c}1.0 \\
\downarrow\end{array}$ & $2 \sim$ & $\begin{array}{c}0.35 \\
\downarrow\end{array}$ & $\begin{array}{c}0.5 \\
\downarrow\end{array}$ & $\begin{array}{c}0.01 \\
\downarrow\end{array}$ & $\begin{array}{c}0.2 \\
\downarrow\end{array}$ & $\begin{array}{c}0.01 \\
\downarrow\end{array}$ & - \\
\hline & & $\mathrm{BC} 6 \mathrm{C}$ & $83 \sim$ & ${ }^{4 \sim} 6$ & $\begin{array}{r}4 \sim 6 \\
6\end{array}$ & $\begin{array}{c}1.0 \\
\downarrow\end{array}$ & $\begin{array}{r}4 \sim \\
6\end{array}$ & $\begin{array}{c}0.3 \\
\downarrow\end{array}$ & $\begin{array}{c}0.5 \\
\downarrow\end{array}$ & $\begin{array}{c}0.01 \\
\downarrow\end{array}$ & $\begin{array}{c}0.2 \\
\downarrow\end{array}$ & $\begin{array}{c}0.01 \\
\downarrow\end{array}$ & - \\
\hline \multirow{5}{*}{ Brass } & \multirow[t]{2}{*}{ Copper Al loy-Rods and Bars * } & C3771BD & $\begin{array}{r}57 \sim \\
61\end{array}$ & $\mathrm{Bal}$. & $\begin{array}{c}1 \sim \\
2.5 \\
\end{array}$ & - & \multicolumn{2}{|c|}{$\begin{array}{c}\mathrm{Sn}+\mathrm{Fe} \\
1.0 \downarrow\end{array}$} & - & - & - & - & - \\
\hline & & C3604BD & $57 \sim$ & $\mathrm{Bal}$. & $\begin{array}{r}1.8 \sim \\
3.7 \\
\end{array}$ & - & $\begin{array}{l}\mathrm{Sn}+\mathrm{Fe} \\
1.2 \downarrow\end{array}$ & $\begin{array}{c}0.5 \\
\downarrow\end{array}$ & - & - & - & - & - \\
\hline & Brass Castings & YBsC 3 & 58〜 & 30 & $\begin{array}{r}0.5 \sim \\
3\end{array}$ & $\begin{array}{c}1.0 \\
\downarrow\end{array}$ & $\begin{array}{c}1.0 \\
\downarrow\end{array}$ & $\begin{array}{c}0.8 \\
\downarrow\end{array}$ & - & $\begin{array}{c}0.5 \\
\downarrow\end{array}$ & - & - & - \\
\hline & \multirow{2}{*}{$\begin{array}{l}\text { Dezincification } \\
\text { Proof Brass * }\end{array}$} & DZPB I & 62.4 & $\mathrm{Bal}$. & 2.4 & - & 0.25 & 0.17 & - & - & 0.01 & - & 0.01 \\
\hline & & DZPB II & 62.4 & $\mathrm{Bal}$. & 1.96 & - & 0.28 & 0.16 & - & - & 0.01 & - & - \\
\hline
\end{tabular}

* Drawn bars

きる保証は無い。また，材料選定試験も加速試験でなけ れば実用上役には立たないが，現場とは異なった条件で 行われる試験で正しい評価ができるか疑問である。そこ で, これらの問題を一挙に解決するために極めて工学的 ではあるが次の方法を用いることにした。すなわち，浸 食機構の分かっている加速試験法によって種々の材料の 耐久試験を行い，試験結果に基づいてそれらの耐久性の 順位付けを行う。それが現場の技術者の経験に基づいた 順位と一致すれば，その試験法の浸食機構が事例の機構 であると断定する。また，その試験法を材料選定用に採 用する。

この種の浸食に関する現場の技術者の経験は断片的で はあるが次の通りである。

(1) 一般に青銅の方が黄銅より耐久性が良い。

（2） BCIn 1 と BCIn 6 を比較すると，大きな差はな いが BCIn 6 の方が優れている。

（3）水栓ではないが，給湯器メーカーの経験では C 3604BD より C3771BD の方が優れている。

（4）耐脱亜鉛腐食黄銅 I 製の水栓がこの種の浸食を 受けたことがある。

なお，素材メ一カーの意見によると，耐脱亜鉛腐食黄 銅 II は同 I を改良したもので，静止液中の耐食性に関し ては BCIn 1 に匹敵する性能を有しているはずである。

\section{2. 加速試験法}

上記の事例 (Fig. 1) の浸食機構として, 静止液中 の腐食, キャビテーション・エロージョン・コロージョ ンおよび流れ誘起局部腐食を想定した。それぞれの浸食 について以下のような加速試験を採用した。

\section{1 静止夜中の腐食}

この種の腐食の加速試験法として ISO 6509「黄銅の
脱亜鉛腐食試験法」に準じた方法を用いた。すなわち $75^{\circ} \mathrm{C}$ に保持された二水化塩化銅 (II) $\left(\mathrm{CuCl}_{2} \cdot 2 \mathrm{H}_{2} \mathrm{O}\right)$ の 水溶液 $(12.7 \mathrm{~g} / 1000 \mathrm{ml})$ に, $314 \mathrm{~mm}^{2}$ の試験面を露 出させた試片を浸漬し, 試験液容器を密封した。24 時 間後に秤量によって試片減量を求め, それにより平均腐 食率 $(\mathrm{mm} / \mathrm{y})$ を算出した。この試験では, 試験液に 含まれる 2 価の銅イオン $\mathrm{Cu}^{2+}$ が 1 価に還元されるとき 試片から電子を奪って試片の酸化, すなわち腐食を助長 する。また, 塩化物イオン $\mathrm{Cl}^{-}$は試片表面の保護性酸 化皮膜を劣化させる作用があるものと思われる。なお， 環境の温度を高めにして，化学反応である腐食反応を加 速している。

\section{2 キャビテーション・エロージョン・コロージョン}

この種の浸食の加速試験法として偏心対向型振動試験 法（Fig. 2 (a)）を採用した。SUS 304 ステンレス鋼製 の振動ノズル（口径 $1.6 \mathrm{~mm}$ ） は試験液である水道水 を噴出する $(0.4 \mathrm{l} / \mathrm{min})$ ばかりでなく, 振動数 $20 \mathrm{kHz}$, 振幅 $25 \mu \mathrm{m}$ で振動してキャビテーション気泡を発生さ せる。この気泡が $0.4 \mathrm{~mm}$ の間隔を隔てて設置された 試片の表面で崩壊してキャビテーション・エロージョン を引き起こす。すなわち，金属に機械的損傷を与える。 振動ノズルと試片は同径 $(16 \mathrm{~mm})$ であるが両者は 7 $\mathrm{mm}$ 偏心して設置されているので試片表面上にエロー ジョンが生じない部分が存在する。そこがカソードに, 一方，エロージョンを受ける部分がアノードとなること によってマクロセル腐食が発生し，エロージョンが加速 される。キャビテーション・エロージョン・コロージョ ンの浸食機構は複雑であり, 試験液の違いによって浸食 機構が大きく異なる。そこで本試験方法では既に浸食機 構が詳細に明らかにされている水道水を試験液に選ん だ1)。 


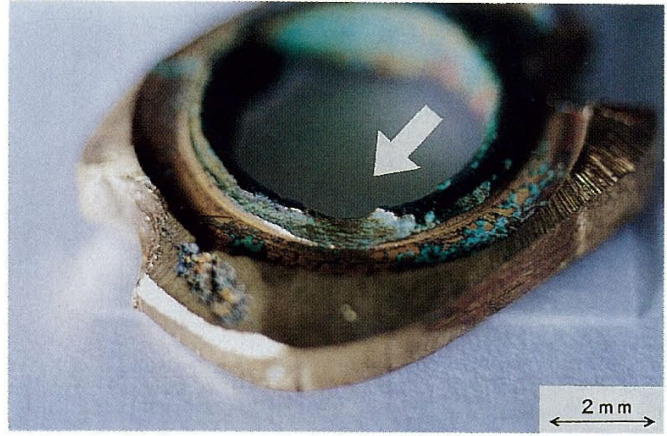

Fig.1 Example of damage on a water tap valve seat after six years in service.
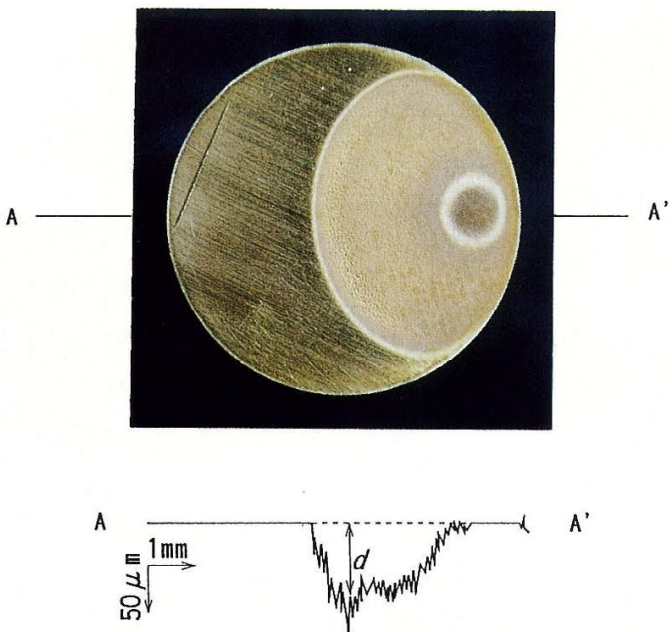

Fig.5 The macrographs of a BCln 6 specimen after $300 \mathrm{~min}$ exposure to cavitation in a vibratory cavitation test and the profile of the damaged surface.

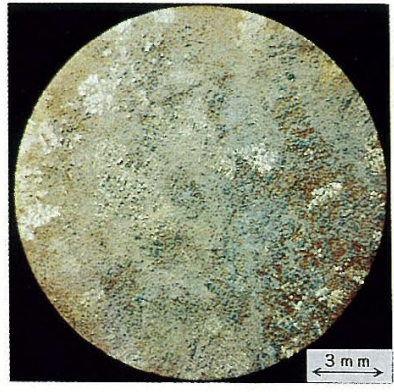

BC I n 6

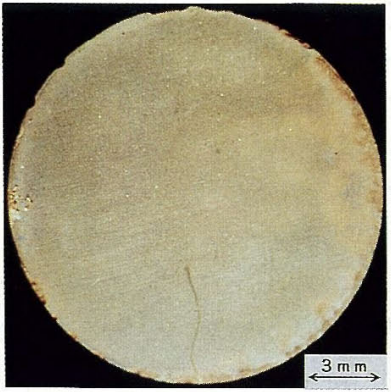

C $3604 B D$

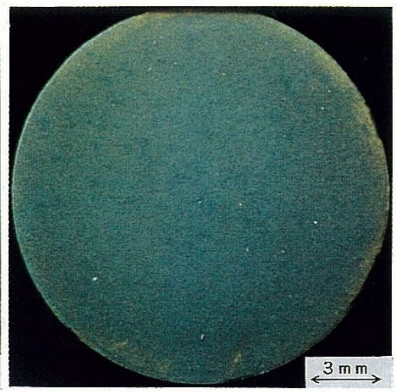

$D Z P B \|$

Fig.3 Macrographs of a test specimen after $24 \mathrm{~h}$ dip in an aqueous solution of copper chloride (II) at $75^{\circ} \mathrm{C}$. Dezincification was recognized for brass specimens but not for bronze specimens at all. The dezincification proof brass bars were also free from damage.

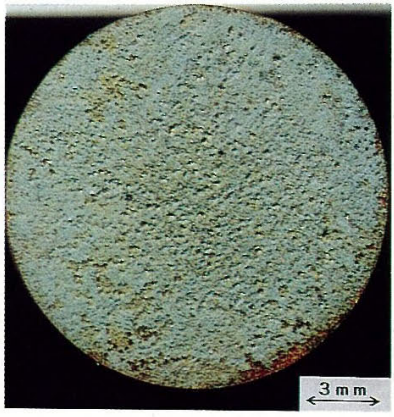

BC $\mid$ ก 6

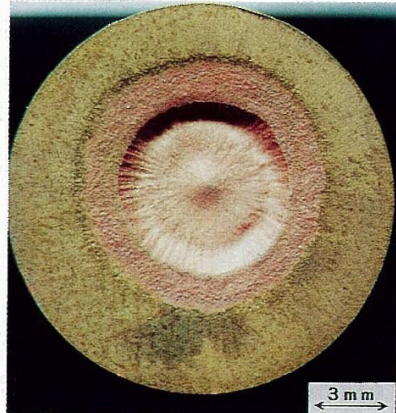

C $3604 B D$

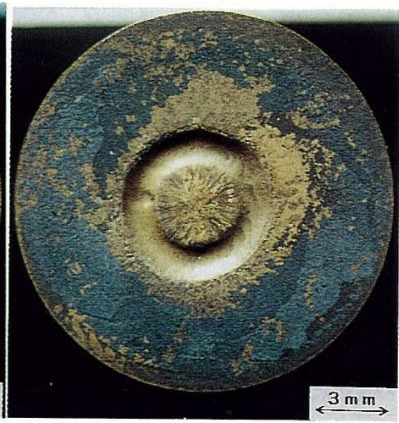

D ZPB I

Fig.8 Macrographs of a specimen after 420 min in a Jet-in-Slit test. The bronze specimens were covered with a relatively thick layer of corrosion. The brass specimens showed dezincification as well as flow induced localized corrosion. The dezincification proof brass specimens suffered the flow induced localized corrosion but not dezincification. 


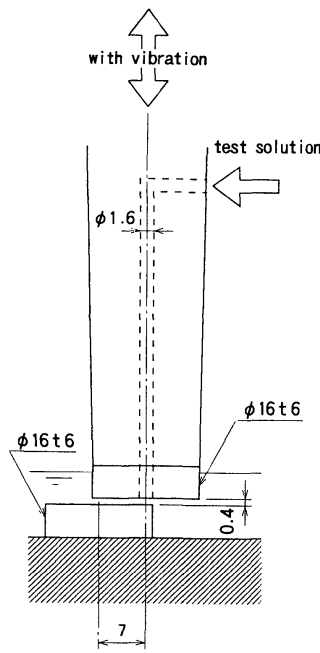

(a)

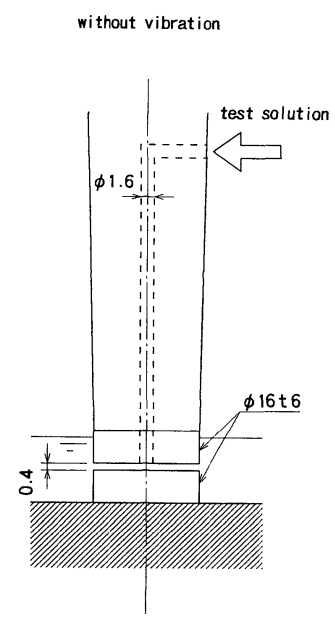

(b)

Fig.2 Experimental devices; (a) Vibratory unit with eccentric stationary specimen for cavitation erosion-corrosion test : frequency, 20 $\mathrm{kHz}$ : double amplitude, $25 \mu \mathrm{m}$ : (b) Jetin-Slit for flow induced localized corrosion : slit, $0.4 \mathrm{~mm}$ : the flow rate of test solution, $0.4 \mathrm{l} / \mathrm{min}$.

\section{3 流れ誘起局部腐食}

この種の浸食の試験法として隙間噴流法試験を選ん だ。同径 $(16 \mathrm{~mm})$ の円盤状のノズルと試片を隙間 $(0.4$ $\mathrm{mm}$ ）を隔てて重称，その隙間へ上側の円盤（アクリル 樹脂製)の中心部に設けられたノズルロ（直径 $1.6 \mathrm{~mm}$ ) を通して試験液，すなわち二水化塩化銅（II）の水溶液 $\left(\mathrm{CuCl}_{2} \cdot 2 \mathrm{H}_{2} \mathrm{O}, 12.7 \mathrm{~g} / 1000 \mathrm{ml}\right)$ を注入した（Fig. 2 （b））。試験液は隙間を満たして試片表面を放射状に流 れる。試験液の流量は $0.4 \mathrm{l} / \mathrm{min}$ で, ノズル内の流速 は3. $3 \mathrm{~m} / \mathrm{sec}$ であるが，隙間では周辺に近づくにつれて 流れ断面積が増大するので流れは減速される。その減速 によって激しい乱れが生じ，それが流れの剪断力と共に 作用して試片表面の保護性酸化皮膜を破壊し, 下地金属 が直接腐食液に曝されて，そこに円環状の局部腐食，す なわち流れ誘起局部腐食が生じることが既に確認されて (いる2),3)。

\section{3. 試 験 結 果}

Fig. 3 に $75^{\circ} \mathrm{C}$ の二水化塩化銅（II）水溶液に 24 時間 浸漬した後の試片の状態を示す。ただし，青銅の代表と して BCIn 6，黄銅の代表として C3604BD，耐脱亜鉛 腐食黄銅の代表として DZPB II のそれらを示した。黄 銅には程度の差はあるもののすべてに脱亜鉛腐食が認め られた。しかし，青銅や耐脱亜鉛腐食黄銅にはそれが認

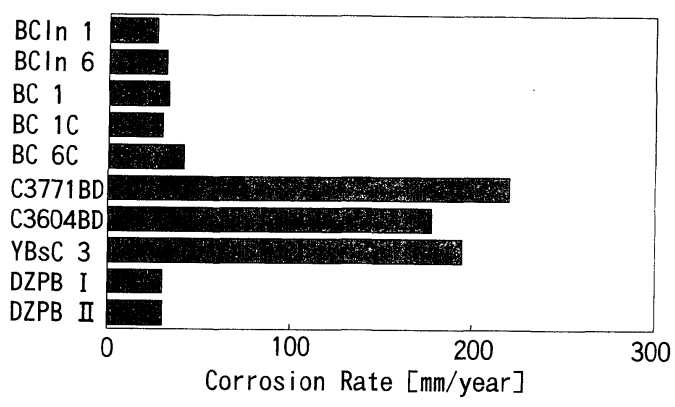

Fig.4 Pure corrosion rates based on mass losses of copper alloys determined by $24 \mathrm{~h}$ dip test.

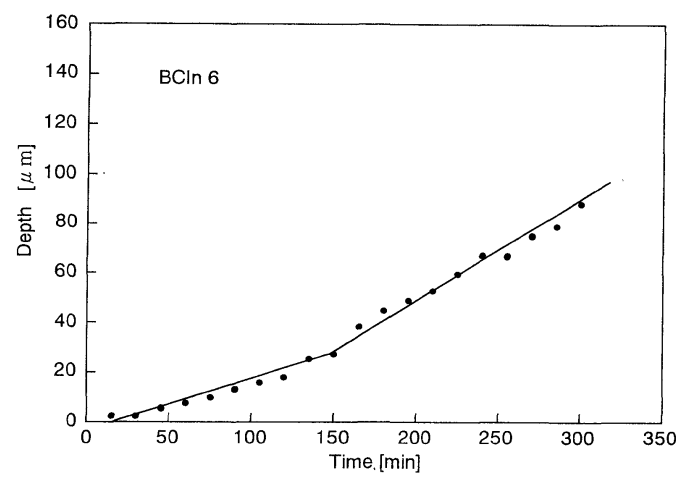

Fig.6 Damage depth vs. testing time for a BCIn 6 specimen obtained in a vibratory cavitation test. The relationship between depth and exposure time was linear and was inclined upwards.

められなかった。Fig. 4 は 24 時間後の試片の減量から 算出された平均腐食率 $(\mathrm{mm} / \mathrm{y})$ を比較したものであ る。この結果を現場の技術者の経験と比較すると，一般 に黄銅に比較して青銅の方が優れているという点では一 致している。しかし, BCIn 6 と BCIn 1 の優劣, およ び C3771BD と C3604BD の優劣は，いずれも現場の経 験と相違している。さらに DZPB I は BCIn 6 と同程度 の耐久性を示した。従ってこの試験は Fig. 1 に示され た浸食を再現しているとは言えない。

$$
\text { キャビテーション・エロージョン・コロージョン試験 }
$$

では, 試片は材質にかかわらずほとんど同様の状態を示 した。浸食の指標として浸食深さを採用した。すなわ ち, 試片を一定時間キャビテーションにさらした後, 表 面粗さ計を用いて表面の起伏を測定し, 試片上の同一場 所における試験前の表面の位置から，そのときの表面ま での距離 $d(\mu \mathrm{m})$ を求めた（Fig. 5)。BCIn 6 につい て得られた損傷深さと時間の関係を Fig. 6 に，また 10 種類の銅合金についてこの関係を比較したものを Fig.7 に示す。 $d$ vs. $t$ 関係はいずれも直線を呈したが，青銅 


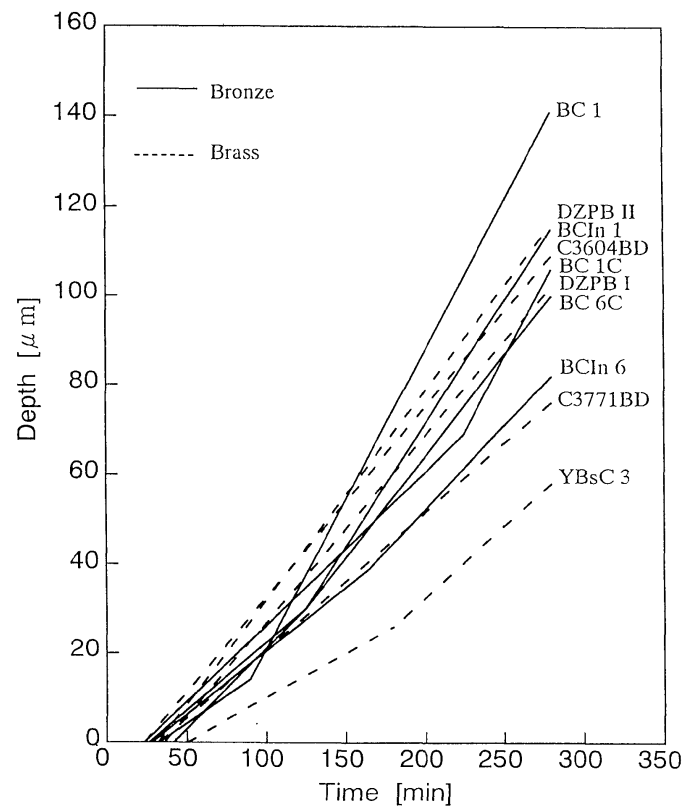

Fig.7 Damage depth vs. testing time for copper alloys obtained in a vibratory cavitation test. All the alloys showed linear relationships, but the casting materials exhibited break point on the relationships. This result indicates the superiority of bronzes over brasses.

のそれらは折れ点を有している。従って試験時間によっ て浸食深さの順位が変化するので評価は難しいが, 全般 的に見れば青銅の方が黄銅よりも $d$ が大きい。この優 劣の順序は先に述べた現場の技術者の経験（1）に反し ている。従って, この試験法も Fig. 1 の浸食を再現し ているとは言えない。

Fig. 8 に隙間噴流法試験に $420 \mathrm{~min}$ 浸食させた後の 代表的な試片の状態を示す。青銅の表面はいずれも比較 的厚い腐食生成物皮膜に覆われた。一方, 黄銅類には脱 亜鉛腐食 (変色によって確認) ばかりでなく, 円環状の 局部腐食が生じた。而脱亜鉛腐食黄銅には脱亜鉛腐食は 生じなかったが，円環状の局部腐食が生じた。Fig. 9 にBCIn 6 について得られた試片減量対試験時間の関係 を示す。この関係において黄銅と青銅は明確に二つのグ ループに分かれた（Fig.10）。すなわち，下に凸の曲線 を呈す，言い換えれば時間と共に浸食率が上昇する黄銅 のグループと, 上に凸の曲線で, すなわち時間と共に浸 食率が低下する青銅のグループである。試験時間の全域 にわたって青銅の方が試片減量も浸食率も小さく，耐久 性に優れていることは明らかである。この優劣の判定は 先に述べた現場の技術者の経験と一致している。また同 じ青銅でも, BCIn 1 より BCIn 6 の方が優れ, 同じ黄

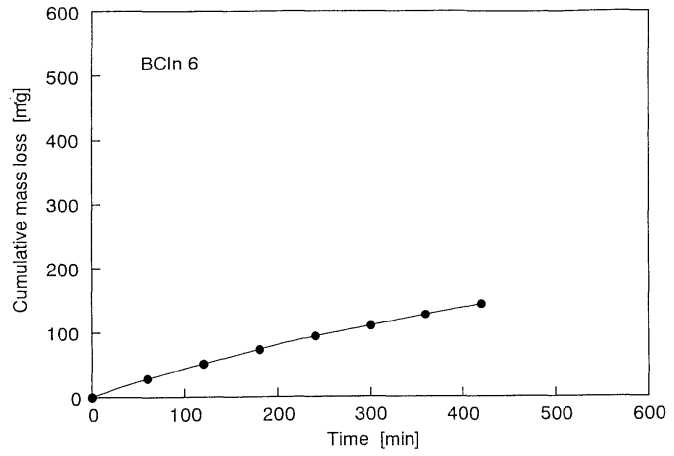

Fig.9 Cumulative mass loss vs. testing time for a BCIn 6 specimen in a Jet-in-Slit test.

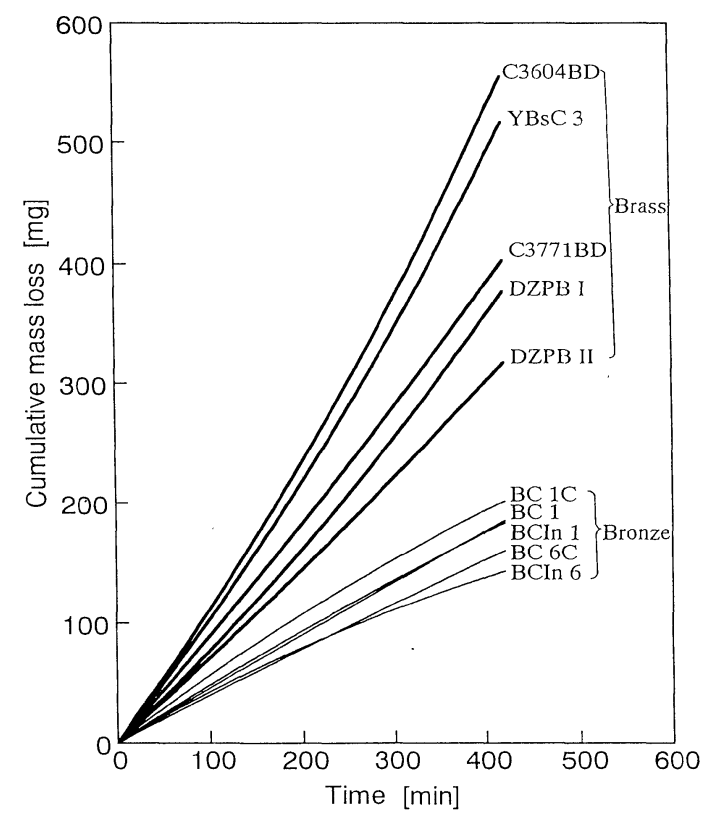

Fig.10 Cumulative mass loss vs. testing time for copper alloys obtained in a Jet-in-Slit test. The bronze curves were convex, which indicated corrosion rates decreasing with exposure time. Those of brass were concave indicating the increased corrosion rate with exposure time.

銅でも，C3604BD より C3771BD が優れている。而脱 亜鉛腐食黄銅 I には局部浸食が生じたので, 脱带鉛腐食 は生じないが, 局部腐食が生じる可能性がある。以上の 4点において試験結果と現場の技術者の経験が一致した ので, Fig. 1 の浸食は流れ誘起局部腐食であると断定 された。また，この浸食に対処するための材料選定試験 法として, 試験液に二水化塩化銅（II）水溶液を用いた 隙間噴流法試験が推奨された。 

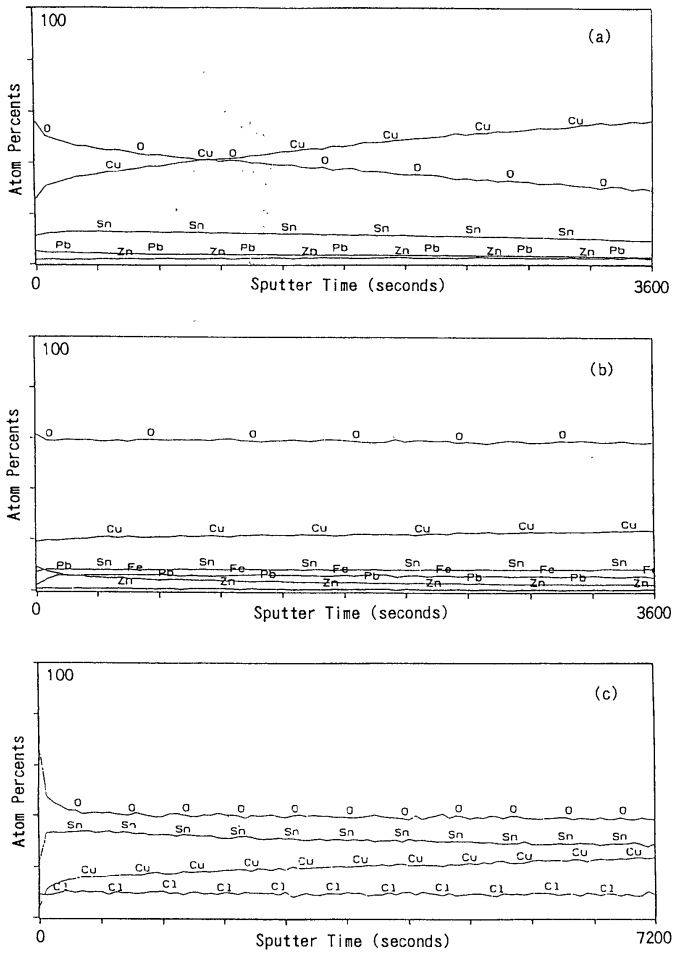

Fig.11 XPS sputtering profile of corrosion layers : (a) Damaged area of water tap valve seats. The main composition of the layers were the oxides of base metal components. (b) Undamaged area of water tap valve seat. The main composition of the layers were the oxides of base metal components, and their distribution was uniform along the depth of the layers. (c) The thick layer formed in the Jet-in-Slit test on BCIn 6 specimen. The major composition of the corrosion products were the oxides of base metal components. The chlorine content was minor.

\section{4. 試験結果の検討}

上記のように, Fig. 1に示した浸食が流れ誘起局部 腐食であると明確に断定することができた理由は，それ ぞれの試験の結果, すなわち供試材料の耐久性順位が, それぞれの浸食機構を反映して互いに相違したためであ る。例えば，静止液中の腐食試験と流れ誘起局部腐食試 験はよく似た結果を示したが, 詳細に検討してみると静 止液中の腐食で而脱亜鉛腐食黄銅 I は青銅と同程度の耐 食性を示したが, 流れ誘起局部腐食では所詮他の黄銅と 同程度の耐食性しか示さなかった。

次の段階として, 上記の試験結果をそれぞれの機構の 浸食に対する材料の優劣の判定だけでなく，材料の相対 的浸食率の予測, さらには定量的な浸食深さあるいは浸
食率の予測に利用できないか検討する。まず静止液中の 腐食試験については, 腐食の進行と時間の関係が全く分 からないので, 定量的な腐食予測はもちろん, 相対的腐 食速度を求めることも出来ない。この試験法の脱亜鉛腐 食感受性試験法としての意義を否定するものではない が, 1 回しか浸食量を測定しないのなら Fig. 4 の腐食 率 $(\mathrm{mm} / \mathrm{y})$ は全く無意味であって,これらの試験結 果は材料間の定量的な優劣の比較にしか用いることはで きない。

キャビテーション・エロージョン・コロージョン試験 に関しては浸食深さと時間の関係が直線を呈する限り, 浸食深さを定量的に推測できることは既に他の報文 ${ }^{4)}$ 述べた。問題はこの直線に折れ点が生ずることである。 折れ点が生じるのは損傷と共に表面粗さが大きくなり多 軸応力が生じるようになるため, 材料の破壊の機構が塑 性変形を伴った延性なものから, 電気化学的腐食の影響 を受けやすい新生面の露出の度合がより大きい脆性的破 壊へ変化するためであること, 折れ曲がりの程度すなわ ち損傷率の増加の程度は非損傷部（カソード）における カソード反応の活発さに依存することが確認されてい る ${ }^{1)}$ 。この折れ点が生ずるときの時間および折れ曲がり の程度を定量的に予測することが残された課題である。

流れ誘起局部腐食に対する材料の耐久性は, 保護性腐 食生成物皮膜に依存している。従って塩化銅（II）水溶 液を用いた加速試験の結果から水道水中の浸食について 定量的な予測が出来るか否かは，塩化銅（II）水溶液が 腐食生成物皮膜の特性に影響を与えるか否かに依存して いる。この点を明らかにするため, 水道水中の浸食事例 の水栓（Fig. 1) に形成された皮膜と加速試験で形成さ れた皮膜（Fig. 7）についてXPS（X 線光電子分光法） 表面分析を行った。分析結果の一部を Fig.11に示す。 Fig.11（a）は事例の損傷部,（b）は事例の非損傷部, (c) は加速試験の BCIn 6 の皮膜分析結果である。分析 結果は微量元素および炭素元素を除いて示してある。他 の試料の分析結果も含めて整理したところ次の事項が明 らかになった。

(1) 加速試験の試片および事例のいずれにおいて も, 浸食部の皮膜厚さは非浸食部のそれの $1 / 10$ 程度で あった。

（2）いずれの試片でも非損傷部では皮膜の化学組成 は皮膜の深さ方向に対して, ほとんど变化しない。

(3) 加速試験で生じた皮膜中の塩素濃度は通常で 1 atm\% 程度（最大で, $10 \mathrm{~atm} \%$ ）であったのに対し， 酸素濃度は 40〜60 atm\%であり, 皮膜中の化合物は塩 化物ではなく素地金属の酸化物が主であった。事例の皮 膜も同様の組成であった。

（4）材料間での比較において, 皮膜の化学組成はそ 
れぞれの材料の素地金属の化学組成を反映していた。

以上の諸点から試片表面には水道水中のそれ之ほぼ同 一組成の腐食生成物が形成され, 浸食機構はほとんど変 わらず，浸食率のみが加速されていると考えられる。 従って，その加速の程度が分かれば，現場における浸食 率を定量的に予測できるし，相対的な浸食率は充分信用 できると思われる。ただし，定量的予測には現場と試験 装置における乱れの強さの比較が必要である。相対的な 浸食率を求める場合は平均浸食率でなく, 浸食深さ率で 比較する必要がある。その場合は黄銅と青銅の耐久性の 差はさらに大きくなる。

\section{5. 結 論}

本研究では 10 種類の銅合金に対して, 静止液中の腐 食, キャビテーション・エロージョン・コロージョン, および流れ誘起局部腐食について加速試験を行った。そ れらの結果を現場の技術者の経験と比較することによっ て, 井戸水や水道水を流す家庭用水栓に生ずる浸食が流 れ誘起局部腐食であるとつきとめた。また, この種の浸 食に対する銅合金の耐久性を半定量的に比較する加速試 験法として隙間噴流法試験が適していることを見い出し
た。

［付記］銅合金に関して貴重な情報を提供して頂いた三 井金属鉱業株式会社圧延加工事業部の山口洋氏，腐食生 成物の分析をお願いした三井石油化学工業株式会社分析 研究所の團野哲也博士, 塩沢一成氏に厚く御礼申し上げ ます。本研究に熱心に協力して下さいました広島大学工 学部化学工学教室の小林康男助手および同卒業論文研究 生の野一色公二君に感謝の意を表します。

(Manuscript received November 4, 1994 ; in final form March 7, 1995)

\section{引用 文 献}

1) 坂本晃大, 船木 宏, 松村昌信 : 材料と環境, 43, 70 (1994).

2 ) M. Matsumura, Y. Oka, S. Okumoto and H. Furuya : ASTM STP 866, 385 (1985).

3 ) 松村昌信, 岡 良則, 横畑英明: 防食技術, 35, 706 (1986).

4 ) M. Matsumura, Y. Oka and A. Sakamoto: Proc. of the Institution of Mechanical Engineers: "Cavitation", p.81 (1992). 